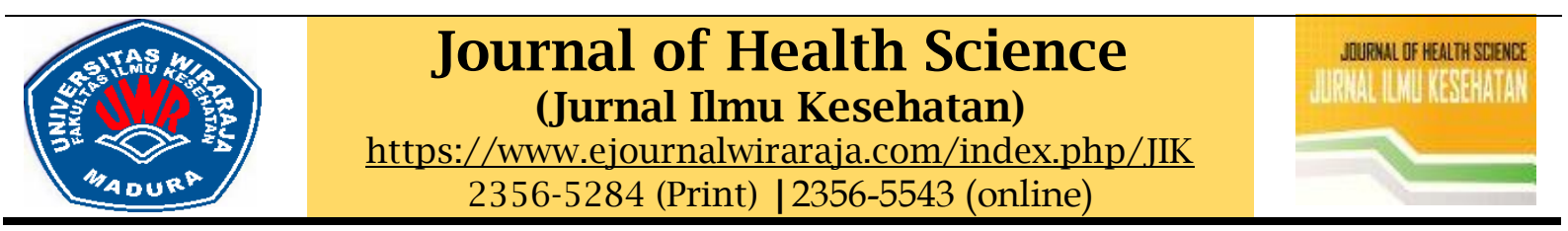

\title{
Pengetahuan dan Sikap Masyarakat dalam Pencegahan COVID-19
}

\section{Emdat Suprayitno', Sylvina Rahmawati ${ }^{2}$, Adivtian Ragayasa ${ }^{3}$, Muchti Yuda Pratama ${ }^{4}$}

${ }^{1}$ Program Studi Profesi Ners Fakultas Ilmu Kesehatan Universitas Wiraraja

${ }^{2}$ Akademi Kebidanan Aifa Husada Madura

${ }^{3}$ Poltekkes Kemenkes Surabaya

${ }^{4}$ Akademi Keperawatan Kesdam I/Bukit Barisan Medan

${ }^{1}$ emdat@wiraraja.ac.id*, ${ }^{2}$ sylvinasantoso@gmail.com, ${ }^{3}$ adivtianragayasa@gmail.com,

${ }^{4}$ yudamuchti@yahoo.co.id

*Corresponding author

\begin{tabular}{ll}
\hline Informasi artikel & ABSTRAK \\
\hline Received:05-10-2020 & Penyakit virus Corona 2019 (Covid-19) telah menjadi pandemi global. Virus \\
Revised: 08-11-2020 & ini mudah menular, sehingga memerlukan pengetahuan dan sikap yang baik \\
Acceptep: 27-11-2020 & dalam upaya pencegahan penularan. Jenis Penelitian ini yaitu deskriptif \\
& dengan desain cross sectional non analitik. Penelitian ini dianalisis secara \\
& deskriptif dengan instrument penelitian kuesioner. Sampel pnelitian ini \\
Kata kunci: & adalah Sebagian masyarakat di Dusun Solo timur dan solo utara Desa \\
Pengetahuan, Sikap, & Murtajih Kecamatan pademawu yaitu sebanyak 62 orang dengan Teknik total \\
COVID-19 & sampling. Penelitian ini bertujuan mengetahui tingkat pengetahuan dan sikap \\
& pencegahan penularan Covid-19 pada masyarakat Desa Murtajih. Hasil \\
& penelitian yaitu tingkat pengetahuan masyarakat dalam pencegahan Covid- \\
& 19 di Desa murtajih kecamatan pademawu adalah sebagian besar baik \\
& sebanyak 32 orang 51,6\%, sedangkan sikap masyarakat dalam pencegahan \\
& Covid-19 di Desa murtajih kecamatan pademawu Sebagian besar positif \\
& sebanyak 53 orang 85,5\%. penelitian ini menhasilkan data Sebagian besar \\
& pengetahuan masyarakat di desa murtajih kabupaten pademawu Sebagian \\
& besar baik dan sikap Sebagian esar positif. Diharapkan masyarakat \\
& melakukan Tindakan pencegahan dalam mencegah penularan COVID-19 \\
& dengan perilaku mencuci tangan dan memakai masker.
\end{tabular}

Key words:

Knowledge, Attitude, COVID-19

\begin{abstract}
Coronavirus disease 2019 (Covid-19) has become a global pandemic. This virus is easily transmitted, so it requires knowledge and a good attitude in efforts to prevent transmission. This research type is descriptive with a cross-sectional non-analytic design. This research was analyzed descriptively with a questionnaire research instrument. The sample of this research is part of the community in the hamlet of East Solo and North Solo, Murtajih Village, Pademawu District, with as many as 62 people with total sampling technique. This study aims to determine the level of knowledge and attitudes to prevent Covid-19 transmission in the people of Murtajih Village. The results showed that the level of public knowledge in preventing Covid-19 in Murtajih Village, Pademawu District was mostly good, as many as 32 people, 51.6\%, while the attitude of the community in preventing Covid-19 in Murtajih Village, Pademawu sub-district was mostly positive as many as 53 people $85.5 \%$. This research produces data. Most of the community knowledge in the village of Murtajih, Pademawu district is mostly good and the attitude is mostly positive. It is hoped that the community will take precautionary measures to prevent transmission of COVID-19 by washing their hands and wearing masks.
\end{abstract}




\section{Pendahuluan}

Sejak penyakit virus korona baru (COVID-19) muncul dari China pada akhir 2019, penyakit ini telah menyebar ke seluruh dunia dengan cepat yang menyebabkan morbiditas dan mortalitas yang signifikan. COVID-19 telah muncul sebagai krisis kesehatan masyarakat secara global. Kasus pertama COVID-19 di India dilaporkan pada $30 \quad$ Januari. 2020. (Muruganandam et al., 2020). Pada 19 April 2020, jumlah kasus COVID-19 yang dikonfirmasi telah melampaui 2. $160.000 \mathrm{di}$ seluruh dunia Lebih dari 82.000 kasus telah dikonfirmasi dan lebih dari 4600 pasien telah meninggal di China. (WHO, 2020). Penyakit Coronavirus 2019 (COVID-19) adalah infeksi yang disebabkan oleh virus korona baru bernama sindrom pernapasan akut parah coronavirus 2 (SARS-CoV2). Kasus pertama infeksi COVID-19 dilaporkan pada Desember 2019 di Wuhan, Cina. Sejak itu, penyakit tersebut telah dinyatakan sebagai pandemi, mempengaruhi lebih dari 4.700.000 orang dan menyebabkan lebih dari 300.000 kematian secara global (Tariq et al., 2020).

Indonesia mulai terpapar oleh virus corona mencapai 172 orang dengan menjadikan jumlah kematian yaitu 55 orang pada tanggal 17 Maret 2020. Seterusnya berlanjut pada 31 Maret 2020, meningkat mencapai jumlah 1.528 orang dan menyebabkan kematian pada 136 orang (Setiati \& Azwar, 2020). Kasus Positif Covid19 pertama kali di Madura terjadi di Kabupaten Pamekasan pada tanggal 30 maret 2020 dengan tambahan 1 pasien dalam pemantauan (PDP) dan 128 Orang dalam pemantauan (ODP), Sedangkan di kabupaten lain di Madura yaitu Bangkalan ada 1 PDP, dan 196 ODP. Sampang ada 87 ODP dan Kabupaten Sumenep ada 65 ODP (Sakti, 2020). Sejak Kabupaten pamekasan berstatus zona merah menyebabkan beberapa masyarakat menjadi resah dan cemas, berdasarkan wawancara dengan 11 warga pamekasan mengatakan bahwa mereka akan lebih berhati-hati dan mematuhi protocol Kesehatan seperti mencuci tangan dan menggunakan masker.

Tanda dan Gejala infeksi Covid-19 yaitu batuk, demam, letih, sesak nafas, dan tidak nafsu makan. Hal ini beda dengan infeksi virus influenza, virus corona dapat berkembang biak secara cepat sehingga menyebabkan keparahan, gagal organ dan kematian. keadaan darurat Kesehatan ini terjadi pada pasien yang memiliki Riwayat penyakit sebelumnya atau komorbid (Mona, 2020). Saat ini tidak ada vaksin atau terapi antivirus khusus untuk infeksi SARS-CoV2. Penatalaksanaan didasarkan pada tindakan pencegahan dan pengobatan gejala orang yang terinfeksi. (Azer, 2020). Langkah untuk pencegahan penularan covid-19 di masyarakat yaitu melakukan secara rutin membersihkan tangan dengan sabun, gunakan hand sanitizer, menghindari menyentuh bagian wajah pada sat tangan kotor, melakukan etika cara batuk dan bersin ang benar, gunakan masker dan jaga jarak (minimal 1 meter) (Jaji, 2020). Penggunaan masker harus sesuai standar masker medis maupun masker kain tidak lebih dari 4 jam, Melakukan sosial distancing dengan jarak minimal 1 meter serta hindari keramaian dengan berbagai kontak fisik, Tidak bepergian keluar kecuali saat darurat, Jangan menyentuh mata, hidung, mulut dengan tangan yang kotor (Nurkholis, 2020). Peneliti belum pernah membaca artikel penelitian pemgetahuan dan sikap masyarakat pada pencegahan Covid-19 di Desa Murtajih. Oleh karena itu tujuan dalam penelitian ini adalah mengetahui pengetahuan dan sikap pencegahan Covid19 pada masyarakat Desa Murtajih Kecamatan Pademawu.

\section{METODE PENELITIAN}

Penelitian ini merupakan jenis deskriptif, dengan pendekatan Cross sectional non analitik. Pengumpulan data dilakukan menggunakan kuesioner dengan pertanyaan tertutup. Sampel pnelitian ini adalah Sebagian masyarakat di Dusun Solo timur dan solo utara Desa Murtajih Kecamatan pademawu yaitu sebanyak 62 orang dengan Teknik total sampling. Pengetahuan diukur dari apakah responden dapat mengetahui penggunaan masker yang benar, manfaat penggunaan masker, cara mencuci tangan yang benar dan manfaat mencuci tangan. sikap diukur dari kesadaran dalam menggunakan masker dan mencuci tangan sebagai pencegahan penularan virus corona Covid-19. Proses penelitian dilakukan dengan mendatangi masing-masing rumah responden dan 
melakukan prosedur protokol Kesehatan pencegahan covid-19. analisa data menggunakan univariate analysis.

\section{HASIL DAN PEMBAHASAN}

\section{Data Umum}

1.1 Tabel 1 distribusi responden berdasarkan usia

\begin{tabular}{ccc}
\hline Usia (tahun) & Jumlah & Prosentase \\
\hline $26-35$ & 3 & 4,8 \\
$36-45$ & 38 & 61,3 \\
$46-55$ & 4 & 6,5 \\
$56-65$ & 13 & 21 \\
$>65$ & 4 & 6,5 \\
\hline Total & 62 & 100 \\
\hline
\end{tabular}

Tabel 1 menunjukkan usia responden mayoritas 36-45 tahun sebanyak 38 orang $(61,3 \%)$.

1.2 Tabel 2 distribusi responden berdasarkan pendidikan

\begin{tabular}{|c|c|c|}
\hline Pendidikan & Jumlah & Prosentase \\
\hline $\begin{array}{c}\text { Tidak } \\
\text { tamat SD }\end{array}$ & 5 & 8,1 \\
\hline SD & 10 & 16,1 \\
\hline SMP & 14 & 22,6 \\
\hline SMA & 21 & 33,9 \\
\hline $\begin{array}{l}\text { Perguruan } \\
\text { tinggi }\end{array}$ & 12 & 19,4 \\
\hline Total & 62 & 100 \\
\hline $\begin{array}{l}\text { Tabel } 2 \\
\text { responden ma } \\
\text { orang }(33,9 \%) \text {. } \\
\text { 1.3 Tabel } 3 \\
\text { berdasarka } \\
\end{array}$ & $\begin{array}{r}\text { menunjukl } \\
\text { ayoritas S } \\
\text { distrik } \\
\text { n jenis kel } \\
\end{array}$ & $\begin{array}{c}\text { pendidil } \\
\text { sebanyak } \\
\text { respono }\end{array}$ \\
\hline Jenis kelamin & Jumlah & Prosentase \\
\hline Laki-laki & 28 & 45,2 \\
\hline Perempuan & 34 & 54,8 \\
\hline Total & 62 & 100 \\
\hline
\end{tabular}

Tabel 3 menunjukkan jenis kelamin responden mayoritas laki-laki sebanyak 34 orang $(54,8 \%)$.

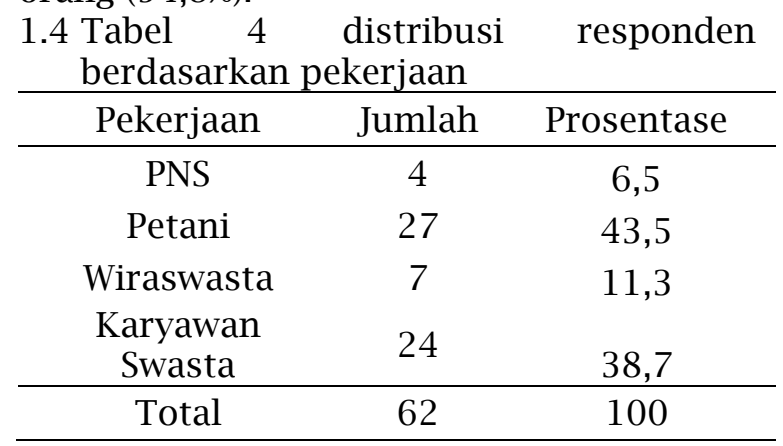

Tabel 4 menunjukkan pekerjaan responden mayoritas petani sebanyak 27 orang $(43,5 \%)$.

1.5 Tabel 5 distribusi responden berdasarkan pengetahuan pencegahan Covid-19

\begin{tabular}{|c|c|c|}
\hline Pengetahuan & Jumlah & Prosentase \\
\hline Baik & 32 & 51,6 \\
\hline Cukup & 23 & 37,1 \\
\hline Kurang & 7 & 11,3 \\
\hline Total & 62 & 100 \\
\hline $\begin{array}{ll}\text { Tabel } 5 & \text { me } \\
\text { responden } & \text { pad }\end{array}$ & ukkan & $\begin{array}{l}\text { oengetahual } \\
\text { n Covid-1 }\end{array}$ \\
\hline
\end{tabular}

1.6 Tabel 6 distribusi responden berdasarkan Sikap pencegahan Covid-19

\begin{tabular}{ccc}
\hline Sikap & Jumlah & Prosentase \\
\hline Positif & 53 & 85,5 \\
Negatif & 9 & 14,5 \\
\hline Total & 62 & 100 \\
\hline
\end{tabular}

Tabel menunjukkan sikap responden pada pencegahan Covid-19 mayoritas baik sebanyak 53 orang $(85,5 \%)$.

\section{PEMBAHASAN}

\section{Pengetahuan Pencegahan Covid-19}

Berdasarkan hasil penelitian di dapatkan Sebagian besar tingkat pengetahuan masyarakat desa pademawu adalah baik 32 oranh (51,6\%). Sejalan dengan hasil peneltian purnamasari 2020 bahwa pengetahuan masyarakat Kabupaten Wonosobo tentang Covid 19 berada pada kategori Baik (90\%) (Purnamasari \& Raharyani, 2020). Penelitian yang dilakukan oleh Yanti B, dkk (2020) yang menyebutkan bahwa 99\% masyarakat Indonesia mempunyai pengetahuan yang baik, 59\% (Yanti et al., 2020). Masyarakat yang memiliki pengetahuan baik juga memiliki sikap dan perilaku yang baik pula.Selain itu, tingkat pengetahuan yang tinggi ini juga didukung dengan tingkat pendidikan sebagian besar responden adalah pendidikan tinggi (diploma dan sarjana).Tingkat pendidikan seseorang yang tinggi akan semkin mudah untuk mendapatkan akses informasi tentang suatu permasalahan (Yanti B dkk, 2020).

Salah satu faktor nternal yang mempengaruhi tingkat pengetahuan seseorang adalah tingkat pendidikan, semakin tinggi tingkat pendidikan 
seseorang maka semakin tinggi pula pengetahuan (Notoatmodjo, 2010). Pengetahuan pencegahan Covid 19 pada masyarakat sangatlah penting pada saat pandemic yang meliputi penyebab penularan covid-19, karakteristik virus, tanda dan gejala, pemeriksaan yang dilakukan dan proses penyebaran serta cara pencegahannya. Beberapa penelitian menunjukkan penggunaan masker wajah oleh masyarakat umum berpotensi bernilai tinggi dalam membatasi penularan Covid-19 (Eikenberry et al., 2020). Pengetahuan masyarakat desa murtajih yang tinggi tentang covid 19 ini berpengaruh terhadap kejadian dan pencegahan penyakit Covid19. Pengetahuan yang baik dapat didukung oleh penerimaan terhadap informasi yang beredar di masyarakat tentang covid 19 (Tri, 2020)

\section{Sikap Pencegahan Covid-19}

Berdasarkan hasil penelitian di dapatkan Sebagian besar sikap masyarakat desa murtajih dalam pencegahan Covid-19 adalah positif sebanyak 53 orang 85,5\%. Sikap responden ini dipengaruhi oleh pengetahuan responden yang baik dimana Seseorang yang telah mengetahui tentang suatu informasi tertentu, maka dia akan mampu menentukan dan mengambil keputusan bagaiman dia harus menghadapinya. Dengan kata lain, saat seseorang mempunyai informasi tentang Covid-19, maka ia akan mampu untuk menentukan bagaimana dirinya harus berperilaku terhadap Covid-19 tersebut (Ahmadi,2013).

Hasil ini sejalan dengan penelitian sari 2020 Sebanyak 201 orang memiliki pengetahuan yang baik (98\%) dan sikap positif (96\%) mengenai pandemi COVID-19 (Sari et al., 2020). Penelitian kabede 2020 mayoritas, 170 (68,8\%), merasa bermanfaat dan penting untuk mengendalikan Covid-19 (Kebede et al., 2020). Penelitian yanti 2020 yaitu mayoritas masyarakat Indonesia (59\%) memiliki sikap positif tentang social distancing untuk mencegah penularan COVID-19 (Yanti et al., 2020). Notoatmodjo (2014) menyebutkan bahwa sikap merupakan konsep yang sangat penting dalam komponen sosio-psikologis, karena merupakan kecenderungan bertindak, dan berpersepsi. Menurut Azwar (2012) Faktorfaktor yang mempengaruhi sikap Media elektronik ataupun cetak sangat berpengaruh kepada terbentuknya pendapat dan kepercayaan seseorang. pemberian informasi dengan media masa mengenai sesuatu hal dapat melandasi kognitif baru terbentuknya sikap (Azwar, 2013). (Eka Meiri, dkk, 2020).

Hasil dari penelitian juga didukung dengan pendidikan responden yang sebagian besar berpendidikan SLTA, diploma / sarjana dimana ssecara umum seseorang dengan pendidikan yang lebih tinggi akan memiliki pengetahuan yang lebih luas. Seseorang dengan pendidikan yang lebih tinggi apabila di berikan stimulus tentang pendidikan kesehatan maka akan bersikap terhadap stimulus yang telah diberikan, sehingga sikap sejalan dengan pengetahuan kesehatan yang dimiliki seseorang (Suprayitno et al., 2020). menurut Daniel Tolossa (2014) rendahnya pengetahuan seseorang tentang TB dapat mempengaruhi pengetahuan dan sikap kesehatan. Pengetahuan dan sikap dapat dilihat bagaimana pemahaman penyakit tentang gejala, penyebab, cara pencegahan. Penderita TB paru yang mendapatkan pendidikan kesehatan pengetahuannya secara otomatis akan meningkat, maka akan diikuti perubahan sikap yang lebih baik dan akan diikuti perubahan perilaku untuk mematuhi program pengobatan (Azwar, 2013), (Suprayitno, 2018).

Sikap dapat menjadi suatu predisposisi untuk bersikap dan bertindak. Faktor penyebab terjadinya perilaku pada diri seseorang merupakan pengetahuan dan sikap seseorang terhadap apa yang telah dilakukan, Perubahan pengetahuan dan sikap individu dimulai dengan tahap kepatuhan, melakukan identifikasi kemudian menjadi internalisasi. Mula-mula seseorang mematuhi anjuran atau instruksi petugas kesehatan tanpa kesadaran untuk melakukan tindakan dan seringkali melakukan instruksi karena adanya hukuman, tapi apabila mendapatkan imbalan/reward mereka akan mematuhi anjuran tetapi masih bersifat sementara (Suharto et al., 2020). Maknanya tindakan itu dilakukan selama dalam pengawasan, sehingga perlu terus dilakukan pemantauan agar perubahan perilaku bersifat menetap. Perubahan perilaku individu menjadi optimal jika perubahan terjadi melalui proses kesadaran dalam diri individu, dimana perilaku yang baru dianggap bernilai positif bagi individu setelah diaplikasikan dengan tindakan individu dapat menjadi lebih baik (Azwar, 2013) 
Hasil dari penelitian juga didukung dengan pendidikan responden yang sebagian besar berpendidikan SLTA dan diploma/sarjana dimana ssecara umum seseorang dengan pendidikan yang lebih tinggi akan memiliki pengetahuan yang lebih luas (Permatasari \& Suprayitno, 2020). Seseorang dengan pendidikan yang lebih tinggi apabila di berikan stimulus tentang pendidikan kesehatan maka akan bersikap terhadap stimulus yang telah diberikan, sehingga sikap sejalan dengan pengetahuan kesehatan yang dimiliki seseorang, menurut Daniel Tolossa (2014) rendahnya pengetahuan seseorang tentang $\mathrm{TB}$ dapat mempengaruhi pengetahuan dan sikap kesehatan. Pengetahuan dan sikap dapat dilihat bagaimana pemahaman penyakit tentang gejala, penyebab, cara pencegahan. Penderita TB paru yang mendapatkan pendidikan kesehatan pengetahuannya secara otomatis akan meningkat, maka akan diikuti perubahan sikap yang lebih baik dan akan diikuti perubahan perilaku untuk mematuhi program pengobatan (Azwar, 2013; Hayati \& Musa, 2016).

Hasil penelitian ini sejalan dengan penelitian bahwa pendidikan kesehatan dengan media audiovisual dapat meningkatkan pengetahuan dan perilaku pola perilaku hidup bersih dan sehat pada pencegahan penularan TB (Hartiningsih, 2018). Hasil penelitian ini juga didukung dengan tingkat pendidikan pada kelompok kontrol 1 sebagian besar berpendidikan minimal SLTA dimana salah satu faktor yang mempengaruhi pengetahuan dan sikap adalah tingkat pendidikan. Tingkat pendidikan yang lebih tinggi akan meningkatakan kemampuan seseorang dalam memahami lebih cepat dari pada yang berpendidikan lebih rendah. Semakin tinggi tingkat pendidikan maka semakin mudah orang tersebut untuk menerima informasi (Hayati \& Musa, 2016).Menurut penelitian Hesti (2016) bahwa semakin tinggi tingkat pendidikan wawasan dan pengetahuan juga akan semakin luas termasuk pengetahuan penderita dan keluarga (Hayati \& Musa, 2016)

\section{KESIMPULAN}

pengetahuan masayarakat di Desa Murtajih Sebagian besar baik dan sikap masyarakat dalam melakukan pencegahan Covid-19 sebagian besar positif. Diharapkan kepada masyarakat untuk melakukan Tindakan pencegahan penularan Covid-19 dengan mematuhi protocol Kesehatan yaitu dengan memakai masker dan rajin mencuci tangan dengan sabun.

\section{DAFTAR PUSTAKA}

Azer, S. A. (2020). COVID-19: Pathophysiology, diagnosis, complications and Investigational therapeutics. New Microbes and New Infections, 100738.

Azwar, S. (2013). Sikap Manusia: Teori dan Pengukurannya. In Sikap Manusia: Teori dan Pengukurannya. https://doi.org/10.1038/cddis.2011.1

Eikenberry, S. E., Mancuso, M., Iboi, E., Phan, T., Eikenberry, K., Kuang, Y., Kostelich, E., \& Gumel, A. B. (2020). To mask or not to mask: Modeling the potential for face mask use by the general public to curtail the COVID-19 pandemic. Infectious Disease Modelling.

Meiri,E., Suprayitno,E., Damayanti, C.N., Fatoni,.A.F. (2020). Hubungan Penggunaan Gadget dengan tingkat Perkembangan Kognitif (Tingkat Prestasi) pada Anak Usia 7-11 Tahun di SDN Kebun Dadap Timur Kabupaten Sumenep. 10(2), 259-266.

Hartiningsih, S. N. (2018). Pengaruh pendidikan kesehatan dengan media audiovisual dan media booklet terhadap perilaku caregiver dalam mencegah tuberkulosis pada anggota keluarga. Health Sciences and Pharmacy Journal, 2(3), 97-102.

Hayati, D., \& Musa, E. (2016). Hubungan Kinerja Pengawas Menelan Obat Dengan Kesembuhan Tuberkulosis Di UPT Puskesmas Arcamanik Kota Bandung. Jurnal Keperawatan BSI, 4(1).

Jaji, J. (2020). PENGARUH PENDIDIKAN KESEHATAN DENGAN MEDIA LEAFLETTERHADAP PENGETAHUAN WARGA DALAM PENCEGAHAN PENULARAN COVID 19. Proceeding Seminar Nasional Keperawatan, 6(1), 135-140.

Kebede, Y., Yitayih, Y., Birhanu, Z., Mekonen, S., \& Ambelu, A. (2020). Knowledge, perceptions and preventive practices towards COVID-19 early in the outbreak among Jimma university medical center visitors, Southwest Ethiopia. PLOS ONE, 15(5), 1-15. https://doi.org/10.1371/journal.pone. 0233744

Mona, N. (2020). Konsep Isolasi Dalam Jaringan Sosial Untuk Meminimalisasi 
Efek Contagious ( Kasus Penyebaran Virus Corona Di Indonesia). Jurnal Sosial Humaniora Terapan, 2(2), 117-125.

Muruganandam, P., Neelamegam, S., Menon, V., Alexander, J., \& Chaturvedi, S. K. (2020). COVID-19 and severe mental illness: impact on patients and its relation with their awareness about COVID-19. Psychiatry Research, 291, 113265.

Notoatmodjo, S. (2010). Ilmu Perilaku Kesehatan, Penerbit Rineka Cipta. Jakarta.

Nurkholis. (2020). Dampak Pandemi NovelCorona Virus Disiase ( Covid-19 ) Terhadap Psikologi Dan Pendidikan Serta Kebijakan Pemerintah. Pgsd, 6(1), 39-49. journal.umc.ac.id/index.php/JPS

Organization, W. H. (2020). Coronavirus disease 2019 (COVID-19): situation report, 72.

Permatasari, D., \& Suprayitno, E. (2020). Implementasi Kegiatan Pendidik Sebaya dan Konselor Sebaya dalam Upaya Pencegahan Triad KRR di Pusat Informasi dan Konseling Remaja. Jurnal Ners Dan Kebidanan (Journal of Ners and Midwifery), 7(1), 143-150.

Purnamasari, I., \& Raharyani, A. E. (2020). Tingkat Pengetahuan dan Perilaku Masyarakat Kabupaten Wonosobo Tentang Covid-19. Jurnal Ilmiah Kesehatan, Mei, 33-42. https://ojs.unsiq.ac.id/index.php/jik/ article/view/1311/783

Sakti. (2020). Satu pasien positif Covid-19 di pamekasan meninggal jadi kasus pertama di madura. https://madura.tribunnews.com/2020 /03/30/satu-pasien-positif-Covid-19di-pamekasan-meninggal-jadi-kasuspertama-di-madura

Sari, D. K., Amelia, R., Dharmajaya, R., Sari, L. M., \& Fitri, N. K. (2020). Positive Correlation Between General Public Knowledge and Attitudes Regarding COVID-19 Outbreak 1 Month After First Cases Reported in Indonesia. Journal of Community Health, 0123456789 .

https://doi.org/10.1007/s10900-02000866-0

Setiati, S., \& Azwar, M. K. (2020). COVID-19 and Indonesia. Acta Medica Indonesiana, 52(1), 84-89.
Suharto, S., Gurning, F. P., Pratama, M. Y., \& Suprayitno, E. (2020). Implementasi Kebijakan Penanggulangan HIV/AIDS di Puskesmas Teladan. Jurnal Riset Hesti Medan Akper Kesdam I/BB Medan, 4(2), 131-136.

Suprayitno, E. (2018). PENGARUH PURSED LIPS BREATHING TERHADAP PEAK EXPIRATORY FLOW RATE PENDERITA PENYAKIT PARU OBSTRUKSI KRONIS. WIRARAJA MEDIKA. https://doi.org/10.24929/fik.v7i2.435

Suprayitno, E., Purnomo, J. D. T., Sutikno, S., \& Indriyani, R. (2020). Health education in principle of community affected teenagaer's smooking attitude and habitual in the coastal area of madura island indonesia. International Journal of Psychosocial Rehabilitation, 24(10), 1492-1502.

https://doi.org/10.37200/IJPR/V24I10 /PR300173

Tariq, R., Saha, S., Furqan, F., Hassett, L., Pardi, D., \& Khanna, S. (2020). Prevalence and Mortality of COVID-19 patients with Gastrointestinal Symptoms: A Systematic Review and Meta-analysis. Mayo Clinic Proceedings.

Tri, S. (2020). Informasi Wabah Virus Covid19: Kuasa Pengetahuan dan Kelas Sosial.

Yanti, B., Wahyudi, E., Wahiduddin, W., Novika, R. G. H., Arina, Y. M. D., Martani, N. S., \& Nawan, N. (2020). COMMUNITY KNOWLEDGE, ATTITUDES, AND BEHAVIOR TOWARDS SOCIAL DISTANCING POLICY AS PREVENTION TRANSMISSION OF COVID-19 IN INDONESIA. Jurnal Administrasi Kesehatan Indonesia, 8(2), 4-14. https://doi.org/10.20473/jaki.v8i2.20 20.4-14 